\title{
B Chromosome System in the Korean Field Mouse Apodemus peninsulae Thomas 1907 (Rodentia, Muridae)
}

\author{
Yuri M. Borisov ${ }^{1}$ and Igor A. Zhigarev ${ }^{2, *(1)}$ \\ 1 Severtzov Institute of Ecology and Evolution, Russia Academy of Sciences, Moscow 119071, Russia; \\ boriss-spb@yandex.ru \\ 2 Institute of Biology and Chemistry, Moscow State University of Education (MSPU), Moscow 129164, Russia \\ * Correspondence: ia.zhigarev@mpgu.edu; Tel.: +7-925-837-3070
}

Received: 30 August 2018; Accepted: 20 September 2018; Published: 27 September 2018

\begin{abstract}
In this paper, we analyzed B chromosome variation in Korean field mouse Apodemus peninsulae Thomas 1907 (Rodentia, Muridae) based on a 40-year study of karyotypes collected from geographically distant populations in East Siberia, North Mongolia, China, the Russian Far East, and Japan (Hokkaido). We developed the database of individual variants of $\mathrm{B}$ chromosome systems in A. peninsulae. In Siberian populations all animals had Bs. The karyotypes of the studied animals contain from 1 to 30 Bs differing in size and morphology. Analysis of B chromosome systems in 598 individuals from different localities of the range shows the presence of 286 variants of Bs combinations in these animals. Unique sets of B morphotypes make up most of these variants (64.7 $\pm 1.3 \%)$, probably suggesting that individual Bs systems normally result from stochastic processes in the populations. The proportion of animals with a large number of Bs gradually decreases, probably due to increased complexities in the inheritance of large numbers of Bs. A. peninsulae is thus proposed as a good model for studying the origin and evolution of extra elements in the karyotype.
\end{abstract}

Keywords: B chromosomes; dot-like (micro) Bs; karyotypic characteristics; Bs; B morphotypes; Apodemus peninsulae

\section{Introduction}

The Korean field mouse (Apodemus peninsulae Thomas, 1907) is widely distributed from East Siberia and North Mongolia, the Russian Far East to China, Korea, and Japan (Hokkaido) (Figure 1). A. peninsulae belongs to the genus Apodemus, in which six species have been shown to carry B chromosomes [1]. A. peninsulae shows one of the widest spectra of Bs variability among animals. Through the wide geographical range mice karyotypes contain from 48 to 78 chromosomes and the vast majority of individuals of this species have supernumerary (B) chromosomes [2-17]. The only population lacking B chromosomes is known from Sakhalin Island, Russia [10]. The Korean field mouse $\mathrm{B}$ chromosomes highly vary in morphology. Most mammals with Bs usually have B chromosomes of one type, such as acrocentric in Apodemus (Sylvaemus) flavicollis Melchior, 1834 or metacentric in Rattus rattus Linnaeus, 1758 [18]. In A. peninsulae up to five morphotypes were revealed [19].

Polymorphism of B chromosomes in A. peninsulae was found in the 1970s while investigating mice karyotypes from Hokkaido, Japan [20]. A range from small dot-like to large metacentric chromosomes was discovered. However, a relative homogeneity of Bs including only small and medium metacentric chromosomes was found in the mainland part of the species range (from Altai to Primorsky Region) [2,4,11]. Further expanding of catching localities in Central Siberia has demonstrated that mainland populations could also have a high variety of B chromosomes $[12,14]$ 
leading to onward investigation of geographic variability of B morphotypes in the Korean field mouse $[1,5-7,14,17,19,21-26]$.

The accumulated knowledge of morphological systems of B chromosomes in A. peninsulae raises new questions: how to estimate population variability of the species through patterns of its B chromosome variability; what meaning B chromosome morphology could have related to its molecular features; how $\mathrm{B}$ chromosomes are originated and inherited?

For over 40 years of the current study nearly 600 individuals of $A$. peninsulae from different parts of its range were karyotyped, making it possible to create an extensive database (http:/ / sev-in.ru/ru/ bdhromosomes-apodemus) and to analyze extra chromosome morphotypes in various geographically distant local populations.

The purpose of the study was to identify common statistical patterns in the distribution of A. peninsulae $\mathrm{B}$ morphotypes in various populations of a wide range.

The Korean field mouse has thus become a good mammalian model for studies of evolutionary dynamics and effects of Bs on the host genome. The aim of this paper is to report new data on B chromosome distribution in local populations of the Korean field mouse A. peninsulae (Rodentia, Muridae) that would determine future directions for investigations.

\section{Materials and Methods}

We examined chromosomal data in 598 A. peninsulae individuals collected at 39 local populations in Russia, Mongolia, China, Korea, and Japan. 418 individuals from 30 localities were collected in Siberia (Central Siberia, Altai, Khakassia, Tyva, Baikal Lake region and Buryatia); 94 individuals were collected from Primorsky krai (the Russian Far East); 60 individuals were collected in Mongolia; 8 individuals were collected in Gansu province of China. Data on B chromosomes were partially published earlier $[9,12,19,21]$. The study protocol was approved by the Ethics Committee of the Severtsov Institute of Ecology and Evolution Russian Academy of Sciences (2017-03-17). All experiments with mice were performed in accordance with the rules approved by the European Convention for the Protection of Vertebrate Animals used for Experimental and other Scientific Purposes. We also used published data on 18 individuals from Hokkaido, Japan [20] (Figure 1, Table 1).

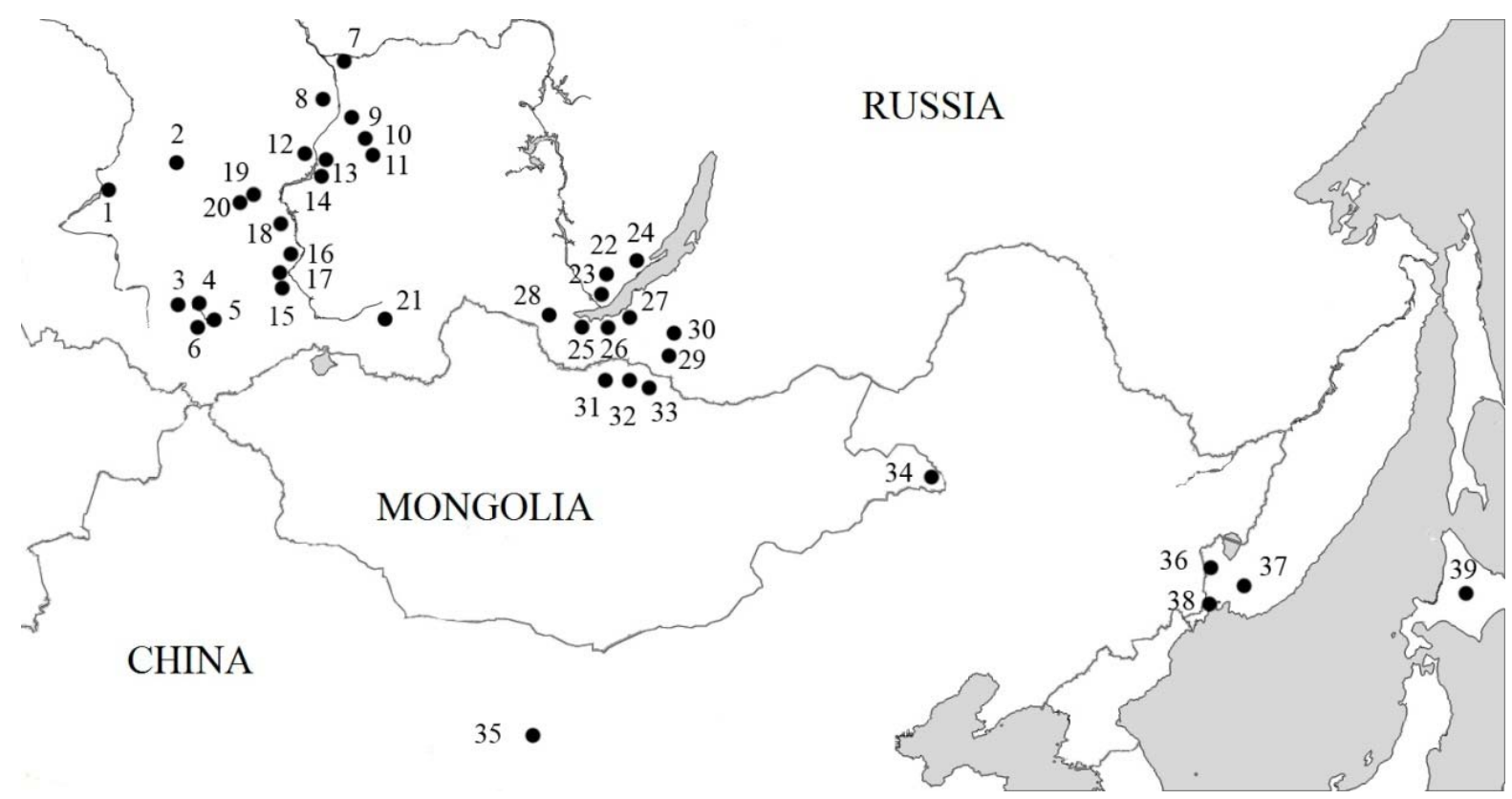

Figure 1. Geographical distribution of $A$. peninsulae and collection numbers. Arabic numbers beside points are location numbers shown in Table 1. 
Table 1. B chromosome characteristics in the Korean field mouse Apodemus peninsulae Thomas, from different localities. For geographical map of localities see Figure 1. mB Index: mass quantity of B chromosomes.

\begin{tabular}{|c|c|c|c|c|c|c|}
\hline \multirow{2}{*}{$\begin{array}{l}\text { No. of } \\
\text { Locality }\end{array}$} & \multirow{2}{*}{ Locality } & \multirow{2}{*}{$\begin{array}{c}\text { No. of } \\
\text { Animals }\end{array}$} & \multicolumn{3}{|c|}{ No. of B Chromosomes } & \multirow{2}{*}{$\begin{array}{l}\text { mB Index } \\
(\mathrm{M} \pm \mathrm{SE})\end{array}$} \\
\hline & & & Total & Macro & Micro & \\
\hline \multicolumn{7}{|c|}{ Russia } \\
\hline 1 & Novosibirsk Region & 20 & $3-14$ & $0-11$ & $0-6$ & $15.8 \pm 1.4$ \\
\hline 2 & Kemerovo Region & 10 & $4-12$ & $3-8$ & $0-4$ & $18.7 \pm 2.1$ \\
\hline $3-6$ & The Altai Republic & 146 & $1-10$ & $1-10$ & $0-3$ & $14.5 \pm 0.5$ \\
\hline 7 & $\begin{array}{l}\text { Angara mouth (between the left } \\
\text { bank of the Angara River and the } \\
\text { right bank of the Yenisei River) }\end{array}$ & 15 & $6-9$ & $6-9$ & 0 & $18.5 \pm 1.1$ \\
\hline 8 & $\begin{array}{l}\text { Central Siberia, the north of } \\
\text { Krasnoyarsk territory, (the left } \\
\text { bank of the Yenisei River) }\end{array}$ & 26 & $4-30$ & 0 & $4-30$ & $18.1 \pm 1.1$ \\
\hline 9 & $\begin{array}{l}\text { Central Siberia, the south of } \\
\text { Krasnoyarsk territory, (the right } \\
\text { bank of the Yenisei River) }\end{array}$ & 40 & $3-18$ & $0-6$ & $1-14$ & $11.2 \pm 0.7$ \\
\hline $10-11$ & $\begin{array}{c}\text { Central Siberia, the east of } \\
\text { Krasnoyarsk territory, Zelenogorsk }\end{array}$ & 5 & $8-17$ & $3-4$ & $5-13$ & $17.6 \pm 1.5$ \\
\hline $12-14$ & Central Siberia, Krasnoyarsk & 47 & $1-10$ & $0-4$ & $0-8$ & $7.7 \pm 0.5$ \\
\hline $15-18$ & The south of Republic of Khakassia & 30 & $1-10$ & $1-6$ & $0-7$ & $8.3 \pm 0.7$ \\
\hline $19-20$ & The north of Republic of Khakassia & 3 & $5-9$ & $5-9$ & $0-1$ & $23.0 \pm 4.6$ \\
\hline 21 & The Tyva Republic & 2 & $12-15$ & 2 & $10-13$ & $15.5 \pm 1.5$ \\
\hline $22-24$ & $\begin{array}{l}\text { Western Baikal (Irkutsk Region, the } \\
\text { western shore of the lake Baikal) }\end{array}$ & 28 & $1-3$ & $1-3$ & 0 & $5.9 \pm 0.4$ \\
\hline $25-30$ & $\begin{array}{c}\text { Southern Baikal (The Republic of } \\
\text { Buryatia) }\end{array}$ & 46 & $2-13$ & $0-5$ & $0-12$ & $11.3 \pm 0.5$ \\
\hline $36-38$ & Primorye (Primorsky krai) & 94 & $0-5$ & $0-5$ & $0-1$ & $4.1 \pm 0.3$ \\
\hline \multicolumn{7}{|c|}{ Mongolia } \\
\hline $31-33$ & Northern Mongolia (West Khentei) & 59 & $2-11$ & $0-6$ & $0-9$ & $7.2 \pm 0.4$ \\
\hline 34 & The Great Khingan & 1 & 1 & 1 & 0 & 3.0 \\
\hline \multicolumn{7}{|c|}{ China } \\
\hline 35 & The Gansu Province & 8 & $7-14$ & $0-3$ & $6-11$ & $12.4 \pm 1.5$ \\
\hline \multicolumn{7}{|c|}{ Japan } \\
\hline \multirow[t]{2}{*}{39} & Island of Hokkaido & 18 & $3-13$ & $0-5$ & $1-9$ & $10.3 \pm 0.9$ \\
\hline & Total & 598 & $0-30$ & $0-11$ & $0-30$ & $10.7 \pm 0.3$ \\
\hline
\end{tabular}

Chromosome preparations were obtained from bone marrow and spleen cells after a routine technique with colchicine treatment [27]. At least 20 metaphase plates from each individual were taken for karyotype analysis. In this paper, we used only modal number of chromosomes; for mosaic animals (with one or none B chromosomes) we took those with one B.

Our own developed formula was applied for morphotype numerical coding of B chromosomes [19]. The first number indicates the amount of Bs. The second number indicates B chromosomes of I class: large bi-armed chromosomes equal to 1-8 pairs of A chromosomes (large metacentrics). The third number indicated B chromosomes of II class: medium sized bi-armed chromosomes equal to 9-16 pairs of A chromosomes (medium metacentrics). The forth number indicates B chromosomes of III class: small bi-armed chromosomes equal to 17-23 pairs of A chromosomes (small metacentrics). The fifth number indicates B chromosomes of IV class: small acrocentric chromosomes equal to 17-23 pairs of A chromosomes. Finally, the sixth number indicates $\mathrm{B}$ chromosomes of $\mathrm{V}$ class or dot-like chromosomes (micro Bs). For example, the formula 5.1.1.1.1.1 
means that an individual has five B chromosomes, one in each of five classes. In our opinion, both the ratio of different $B$ morphotypes and the variety of total amount of chromatin in $B$ chromosomes are highly significant to reveal the origin and specific existence of $B$ chromosomes $[22,23]$. To estimate the amount of chromatin, we used conditional mass quantity of B chromosomes ( $\mathrm{mB}$ index), developed by G.V. Roslik and I.V. Kartavtseva [13]. In this case, one conditional point is assigned to each size class: one point to dot-like (micro Bs) (V class), two points to larger and relatively similar in size chromosomes of IV and III classes, three points to II class and four points to I class chromosomes. The sum of points demonstrates a certain characteristic of Bs mass quantity.

Localities were aggregated according to distances and presence/absence of geographical, especially water, barriers between them.

The statistical analysis using standard techniques was conducted in Statistica 8.0 Software [28].

\section{Results and Discussion}

The analysis of 598 A. peninsulae karyotypes collected at 39 local populations in Russia, Mongolia, China, and Japan revealed presence of B chromosomes in $97.7 \%$ of the species population (Table 1). 12 individuals from the Russian Far East (12.8\% of individuals collected in Primorsky krai) are the only exception with no B chromosomes in their karyotypes (localities no. 36-38, Figure 1). Table 1 summarizes the B chromosome data, including their number and morphology, in each examined locality. We also calculated the frequency of animals with macro and micro B chromosomes using our own information (Table 2).

Table 2. Frequency of $A$. peninsulae individuals with different macro and micro B chromosomes in studied local populations.

\begin{tabular}{ccc}
\hline Chromosome Type & Frequency of Individuals (P) & $\pm \mathbf{S E}$ \\
\hline Large metacentric & 0.28 & 0.018 \\
\hline Medium metacentric & 0.61 & 0.020 \\
\hline Small metacentric & 0.62 & 0.019 \\
\hline Acrocentric & 0.12 & 0.013 \\
\hline Dot-like micro chromosome & 0.53 & 0.020 \\
\hline No extra chromosomes & 0.02 & 0.006 \\
\hline
\end{tabular}

The standard (A) diploid set of $A$. peninsulae contains 48 acrocentric chromosomes gradually decreasing in size (Figures 2 and $3 \mathrm{a}$ ). In addition, up to $30 \mathrm{~B}$ chromosomes may be found in some individuals. In this paper, we divide B chromosomes into two groups according to their size. The first group includes Bs of visible morphology under light microscopy (macro Bs), which are larger or equal in size to the smallest A chromosome. The second group includes only dot-like chromosomes which are much smaller than A chromosomes and without clear morphology (micro Bs). The macro $\mathrm{B}$ chromosomes are divided into classification types according to their morphology and relative size in comparison with the A chromosomes (Figure 3b). Despite high variability of B chromosomes, A chromosome aberrations were not found.

We have previously described four types of macro Bs [12]: (1) large metacentrics or submetacentrics (Lm-sm); (2) medium-to-small metacentrics or submetacentrics (Mm-sm); (3) small metacentric (mm); (4) large-to-small acrocentrics or subtelocentrics (A-St). The most frequent macro Bs in A. peninsulae are Mm-sm (Figure 3a), whereas A-St morphological variants of medium or small size are rare. In some cases, we could identify the morphology of micro Bs in good quality metaphase plates, but in most cases micro Bs resembled very small structures without clear morphology. 


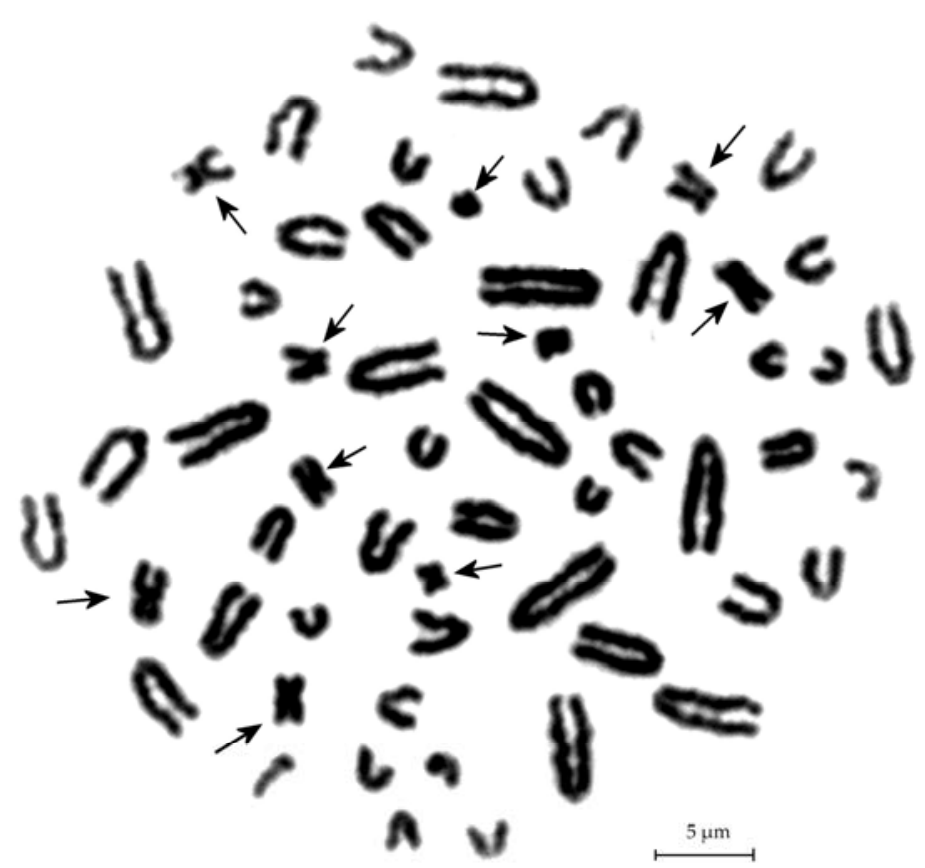

Figure 2. Metaphase plates of $A$. peninsulae with 10 different Bs.

\title{
a

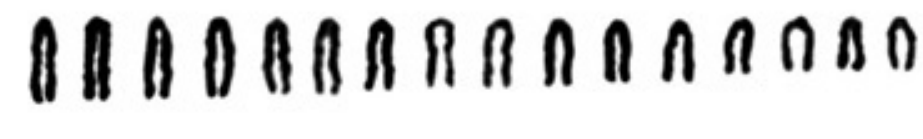

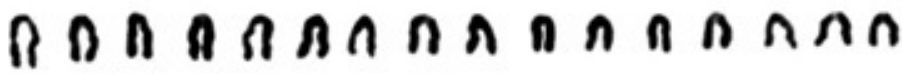

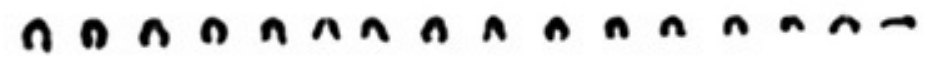

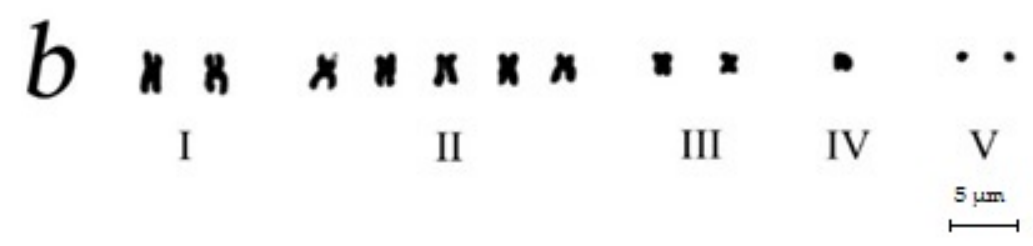

Figure 3. Karyotype of A. peninsulae: (a) the main set of 48 acrocentric A chromosomes and (b) variants of five (I-V) classes of B chromosomes. Formulas of Bs are 12.2.5.2.1.2.

We suppose that dot-like (micro Bs) chromosomes are initial and originated by duplication of centromeric areas of A chromosomes with further reorganization into macro Bs through DNA amplification $[22,23]$.

The frequencies of $A$. peninsulae individuals with one or another extra chromosome type are not equal in nature. Animals carrying even one medium or small metacentric B chromosome are more frequent (Table 2). Dot-like Bs also have relatively high frequency. In contrast, the frequency of large metacentrics across the Korean field mouse range is substantially lower; less than one third of mice caught in nature would have these chromosomes $(p=0.28 \pm 0.018)$. Acrocentric B chromosomes, in their turn, are extremely rare. The similar tendency is shown for the Far East population of A. peninsulae based on the analysis of 367 individuals [13].

The number of large metacentric B chromosomes carried by a single karyotype varies from 0 to 5 across local populations. Their maximum number (4-5) occurs extremely rarely: only two such individuals were recorded in Siberia (Altai and Khakassia). Some mice from Altai, Novosibirsk and 
West Khentei (Mongolia) carried three large chromosomes, though one or two large B chromosome were met much more frequently. Meanwhile, the majority of examined individuals $(72.2 \pm 1.83 \%)$ did not have chromosomes of that type at all (Table 3).

Table 3. Proportion of $A$. peninsulae individuals with different number of B chromosomes (\%, $\pm \mathrm{SE})$ over the species range.

\begin{tabular}{|c|c|c|c|c|c|}
\hline \multirow{2}{*}{$\begin{array}{l}\text { Number of B } \\
\text { Chromosomes }\end{array}$} & \multicolumn{5}{|c|}{ Proportion of Individuals with B Chromosomes } \\
\hline & $\begin{array}{c}\text { Large } \\
\text { Metacentric }\end{array}$ & $\begin{array}{c}\text { Medium } \\
\text { Metacentric }\end{array}$ & $\begin{array}{c}\text { Small } \\
\text { Metacentric }\end{array}$ & Acrocentric & $\begin{array}{c}\text { Dot-Like } \\
\text { (micro Bs) }\end{array}$ \\
\hline 0 & $72.2 \pm 1.83$ & $39.1 \pm 2.00$ & $37.8 \pm 1.98$ & $88.13 \pm 1.32$ & $47.5 \pm 2.04$ \\
\hline 1 & $16.1 \pm 1.50$ & $25.4 \pm 1.78$ & $30.8 \pm 1.90$ & $8.9 \pm 1.16$ & $14.7 \pm 1.45$ \\
\hline 2 & $8.7 \pm 1.15$ & $22.1 \pm 1.70$ & $19.4 \pm 1.62$ & $2.51 \pm 0.64$ & $7.36 \pm 1.07$ \\
\hline 3 & $2.7 \pm 0.70$ & $6.7 \pm 1.00$ & $6.52 \pm 1.00$ & $0.17 \pm 0.17$ & $5.52 \pm 0.93$ \\
\hline 4 & $0.17 \pm 0.17$ & $3.34 \pm 0.74$ & $3.5 \pm 0.75$ & $0.17 \pm 0.17$ & $4.18 \pm 0.82$ \\
\hline 5 & $0.17 \pm 0.17$ & $2.0 \pm 0.57$ & $1.0 \pm 0.41$ & $0.17 \pm 0.17$ & $3.18 \pm 0.72$ \\
\hline 6 & - & $0.84 \pm 0.37$ & $0.84 \pm 0.37$ & - & $2.17 \pm 0.60$ \\
\hline 7 & - & $0.33 \pm 0.23$ & - & - & $1.67 \pm 0.52$ \\
\hline 8 & - & $0.17 \pm 0.17$ & $0.17 \pm 0.17$ & - & $3.18 \pm 0.72$ \\
\hline 9 & - & - & - & - & $2.34 \pm 0.62$ \\
\hline 10 & - & - & - & - & $2.17 \pm 0.60$ \\
\hline 11 & - & - & - & - & $0.84 \pm 0.37$ \\
\hline 12 & - & - & - & - & $0.84 \pm 0.37$ \\
\hline 13 & - & - & - & - & $0.33 \pm 0.24$ \\
\hline 14 & - & - & - & - & $0.84 \pm 0.37$ \\
\hline 15 & - & - & - & - & $0.17 \pm 0.17$ \\
\hline 16 & - & - & - & - & $0.84 \pm 0.37$ \\
\hline 18 & - & - & - & - & $0.67 \pm 0.33$ \\
\hline 20 & - & - & - & - & $0.5 \pm 0.29$ \\
\hline 22 & - & - & - & - & $0.33 \pm 0.24$ \\
\hline 24 & - & - & - & - & $0.33 \pm 0.24$ \\
\hline 26 & - & - & - & - & $0.33 \pm 0.24$ \\
\hline 30 & - & - & - & - & $0.17 \pm 0.17$ \\
\hline
\end{tabular}

The number of medium and small metacentric B chromosomes varies from 0 to 8 across different populations. Unlike macro metacentric chromosomes, their presence in populations is more significant as over $60 \%$ of karyotypes contain Bs of these types (Table 3). A tendency of decreasing proportion of individuals with increasing number of B chromosomes remains (Figure 4). The maximum number of medium (8) and small (8) metacentric chromosomes was recorded only once in karyotypes from left bank of Angara River and Novosibirsk, respectively. Mice with a small number of Bs (1-3) were recorded more often.

A tendency of distribution of acrocentric B chromosomes (IV class) in populations of $A$. peninsulae is similar with that of large metacentric chromosomes (Table 3, Figure 4). The maximum of acrocentric chromosomes (5) was found in a single karyotype from Novosibirsk area.

The number of extra dot-like chromosomes (micro Bs) in different populations varies from 0 to 30 (Table 3). Nearly half of examined Korean field mice ( $47.5 \pm 2.04 \%)$ had no dot-like Bs. The proportion of mice with many dot-like Bs gradually decreased as in case of large B chromosomes (Figure 5).

It is necessary to emphasize that the correlation between the number and the frequency of chromosomes is rather high, negative, and significant in all cases $(p<0.05)$ (Table 4$)$. This may indicate an increase in complexity of inheritance with an increase in the number of B chromosomes in the karyotype, particularly in case of large Bs (I, II and III classes). 


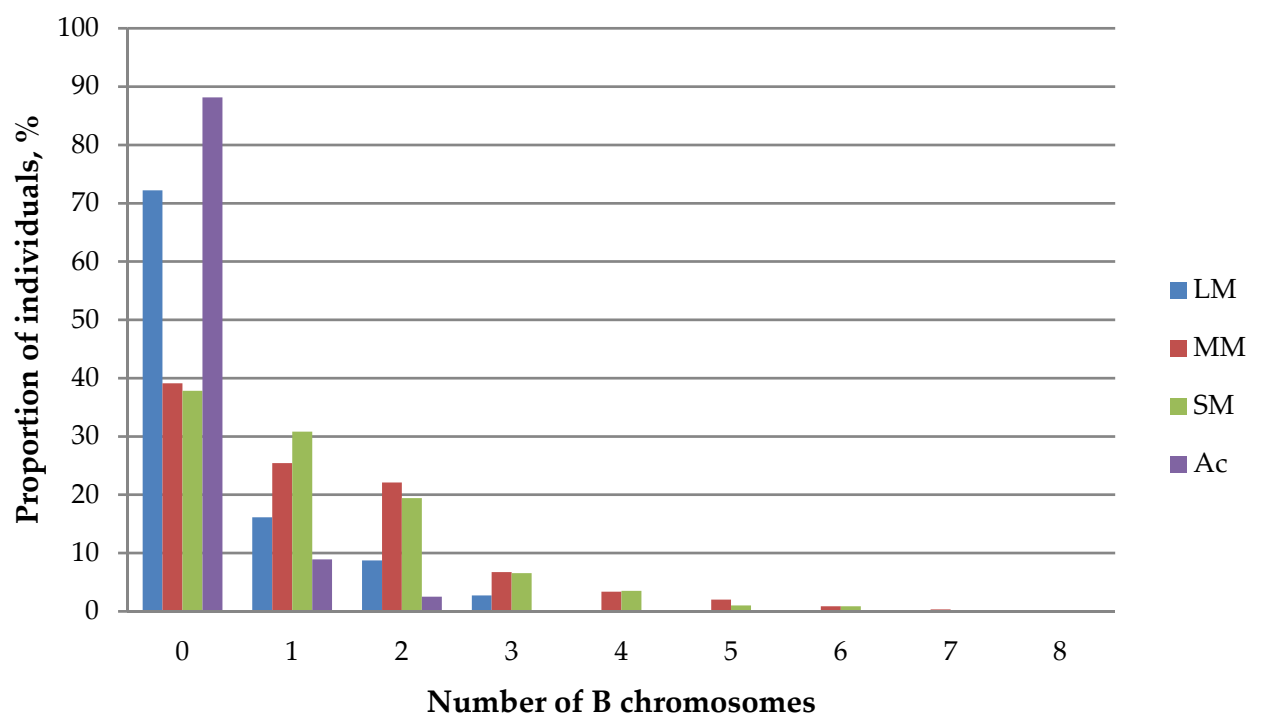

Figure 4. Ratio of $A$. peninsulae individuals with different numbers of $\mathrm{B}$ chromosomes across studied populations. LM: large metacentrics; MM: medium metacentric SM: small metacentric Ac: acrocentric.

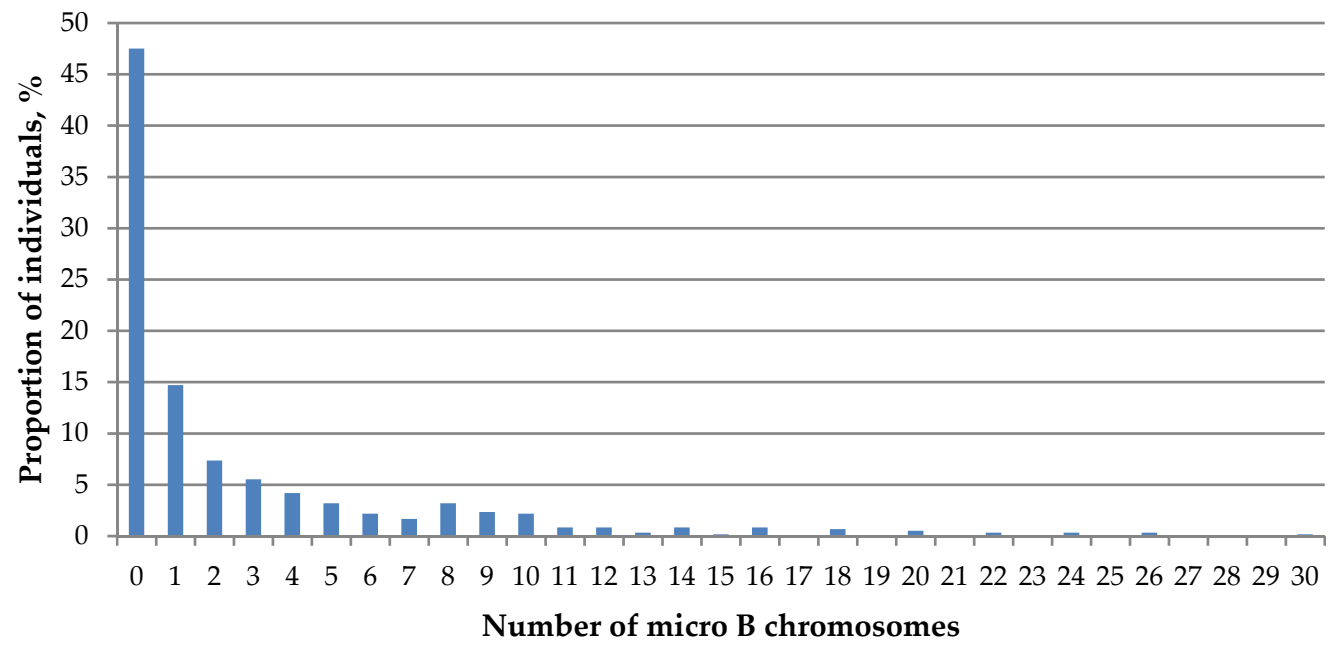

Figure 5. Ratio of A. peninsulae karyotypes with a certain number of micro B chromosomes across studied populations.

Table 4. Correlation between the number and frequency of B chromosomes in karyotypes of A. peninsulae (Spearman's rank test, $p<0.05$ ).

\begin{tabular}{cccccc}
\hline & \multicolumn{5}{c}{ Type of B Chromosome } \\
\cline { 2 - 6 } & $\begin{array}{c}\text { Large } \\
\text { Metacentric }\end{array}$ & $\begin{array}{c}\text { Medium } \\
\text { Metacentric }\end{array}$ & $\begin{array}{c}\text { Small } \\
\text { Metacentric }\end{array}$ & Acrocentric & $\begin{array}{c}\text { Dot-Like } \\
\text { (Micro Bs) }\end{array}$ \\
\hline$r_{\mathrm{S}}$ & -0.986 & -1.00 & -0.98 & -0.94 & -0.9 \\
\hline
\end{tabular}

The frequency of A. peninsulae karyotypes with different numbers of all $\mathrm{B}$ chromosomes differs in some way from the frequencies of certain classes (Figure 6). Individuals with two B chromosomes are recorded much more frequently $(16.39 \pm 2.30 \%)$ than those with only one B chromosome type $(4.85 \pm 0.77 \%)$. In general, two thirds of mice in different local populations have from two to seven $\mathrm{B}$ chromosomes. Thus, we suppose that not just the presence of extra chromosomes, but the presence of several (not one) Bs in A. peninsulae karyotypes is normal for this species.

Overall, even and odd numbers of $B$ chromosomes in a karyotype is not statistically equal (Pearson Chi-square test, $\chi^{2}=6.64, p<0.05$ ). Individuals with an even number of Bs are recorded 
significantly more often $(57.5 \%)$ that indirectly indicates the pattern of inheritance or chromosome division-merging processes.

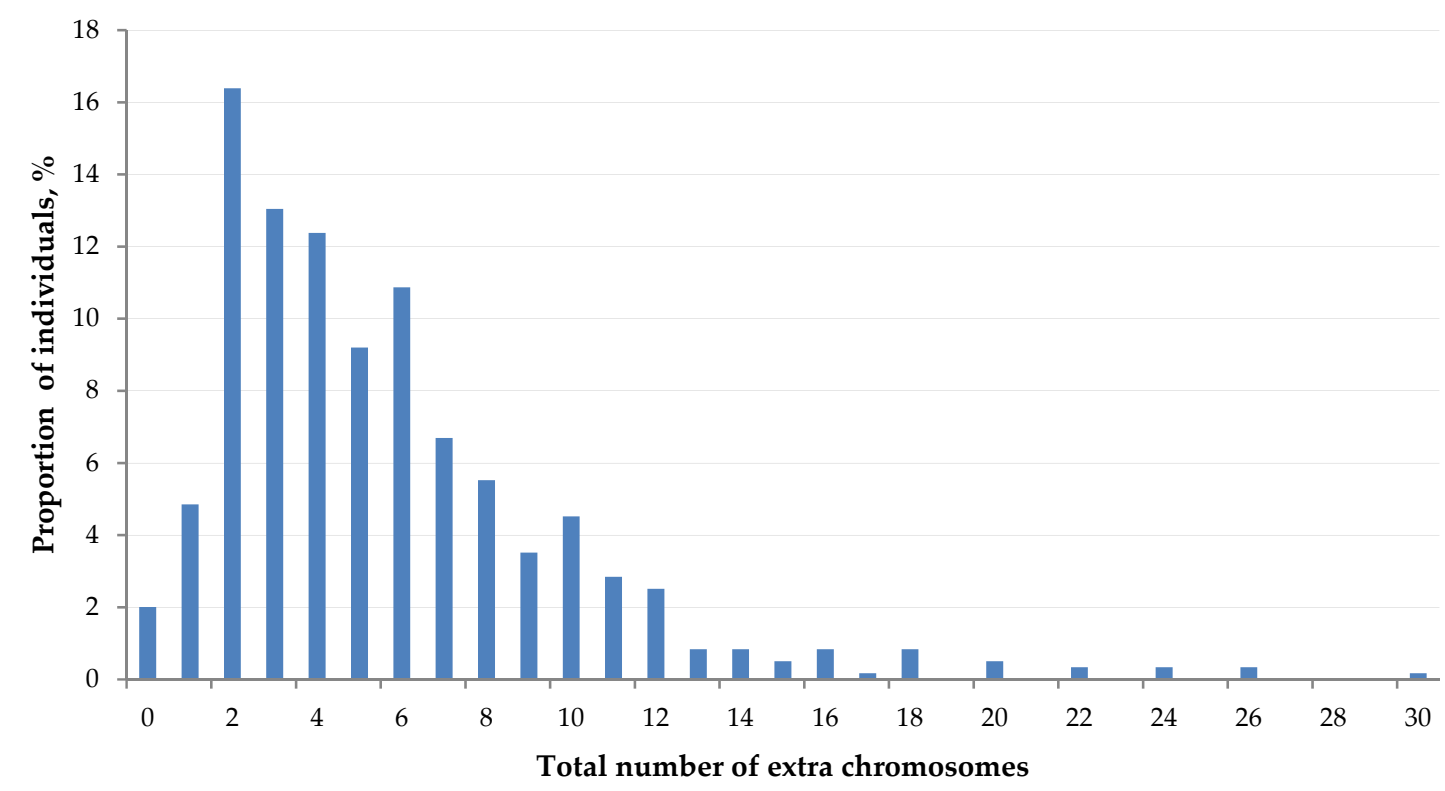

Figure 6. Ratio of A. peninsulae karyotypes with total number of extra chromosomes regardless of the type across examined local populations.

The analysis of extra chromosome systems of 598 A. peninsulae individuals from different parts of the species range demonstrates the high variety of $B$ combinations (286). Wherein, the unique Bs combinations are dominated $(64.7 \pm 1.3 \%$, Table 5$)$ that is likely due to the prevalence of stochastic processes in developing of individual Bs systems. Almost the third of examined animals (31\%) carries the unique combinations of $\mathrm{B}$ chromosomes.

Table 5. The number and ratio of B chromosome systems among A. peninsulae karyotypes across the species range.

\begin{tabular}{cccc}
\hline $\begin{array}{c}\text { Frequency of B Chromosome } \\
\text { System across the Range }\end{array}$ & $\begin{array}{c}\text { Number of } \\
\text { Combinations }\end{array}$ & $\%$ & SE, \% \\
\hline Once (unique) & 185 & 64.7 & 1.3 \\
Twice & 49 & 17.1 & 0.7 \\
3 times & 23 & 8.0 & 0.5 \\
4 times & 11 & 3.8 & 0.3 \\
5 times & 4 & 1.4 & 0.2 \\
6 times & 2 & 0.7 & 0.1 \\
7 times & 2 & 0.7 & 0.1 \\
8 times & 2 & 0.7 & 0.1 \\
9 times & 1 & 0.3 & 0.1 \\
12 times & 2 & 0.7 & 0.1 \\
13 times & 1 & 0.3 & 0.1 \\
15 times & 1 & 0.3 & 0.1 \\
22 times & 1 & 0.3 & 0.1 \\
26 times & 1 & 0.3 & 0.1 \\
31 times & 1 & 0.3 & 0.1 \\
\hline Total number of Bs systems & 286 & & \\
\hline
\end{tabular}

The unique combinations of B chromosomes in mice karyotypes are met more frequently in local populations in Central Siberia and Japan (Figure 7). On the other hand, mice with repeated variants (non-unique) dominated in some well-studied populations such as local populations from the Far East (localities 36-38, $n=94$ ), Western Baikal (localities 22-24, $n=28$ ) and the left bank of Yenisei River (the locality $8, n=26$ ) (Figure 7). 


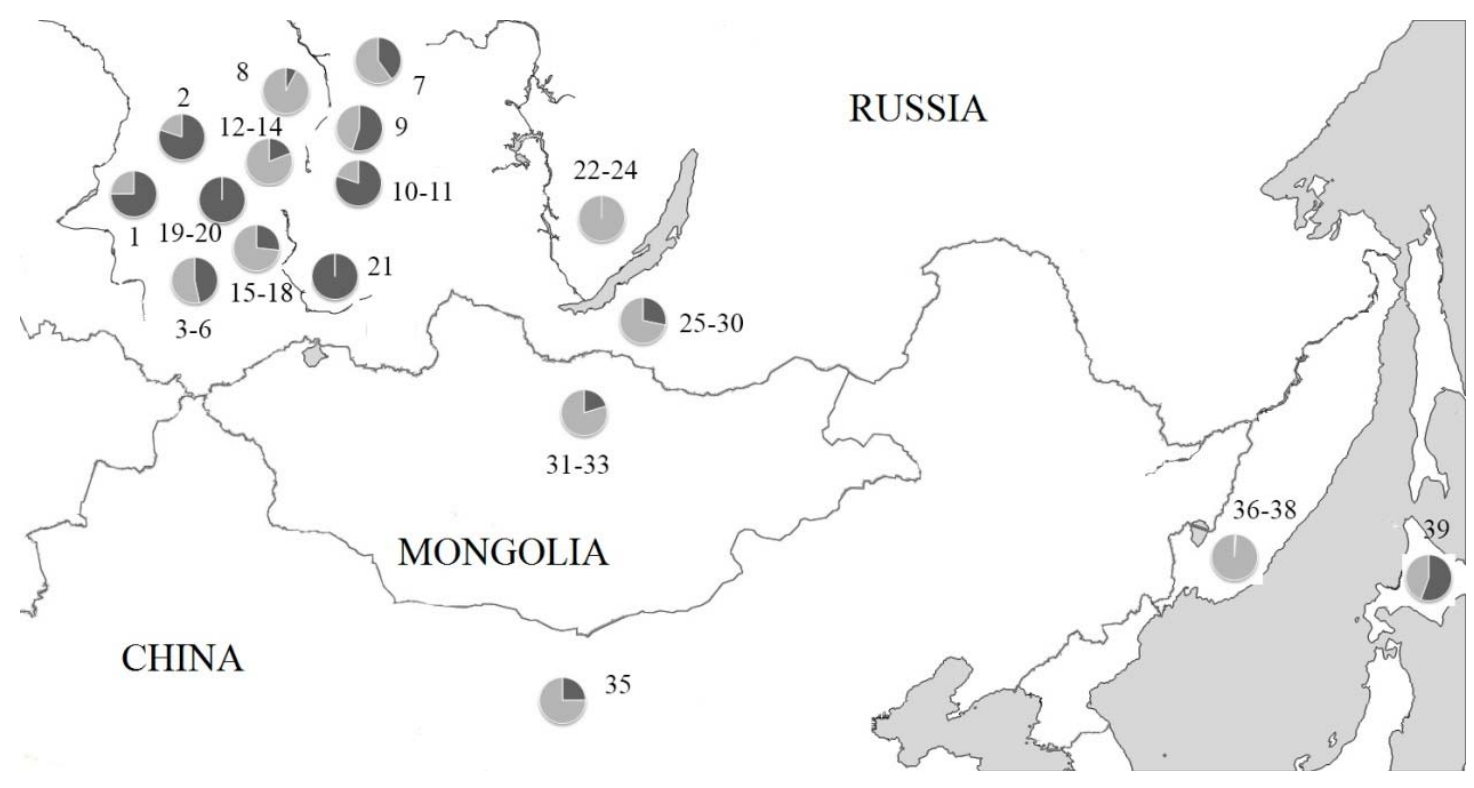

Figure 7. The proportion of animals in A. peninsulae local populations carrying unique B chromosome combinations (dark shading). Arabic numbers beside points are location numbers shown in Table 1.

Moreover, combinations with few numbers of Bs (0-4) are more frequent (the absence of $\mathrm{B}$ chromosomes was considered as one of 286 variants). The number of chromosomes in a combination negatively correlated with its frequency (Spearman's rank test, $\mathrm{r}_{\mathrm{s}}=-0.33, p<0.05$ ). In other words, the more there are $\mathrm{B}$ chromosomes in a karyotype, the less these combinations repeat across the species range and more often become unique. The most repeated was the combination of two small metacentrics recorded 31 times in different geographical regions: Khakassia, Western Baikal, Northern Mongolia and Primorye. The combination of one medium and one small metacentric was recorded 26 times and the combination of two medium metacentrics was recorded 15 times in Altai, Khakassia, Western Baikal, Northern Mongolia and Primorye populations. The variant with one small metacentric was found 22 times Khakassia, Western Baikal and Primorye populations. Combinations recorded twice constitute a considerable part $(17.1 \pm 0.7 \%)$.

The analysis of conditional mass quantity of B chromosomes ( $\mathrm{mB}$ index) enabled us to compare samples with different amounts of extra chromatin in mice cells from different geographical populations. The lowest values were recorded in Primorsky krai $(4.1 \pm 0.3$, Table 1$)$ and the highest values were recorded in Kemerovo region and the south of Krasnoyarsk region ( $\mathrm{mB}$ index $>18$ ). Overall, the average $\mathrm{mB}$ index value across the western part of the A. peninsulae range (Central Siberia; $13.4 \pm 0.35$ ) almost twice higher than that across the eastern and southern parts (Baikal region, the Russian Far East, Japan, Mongolia, and China; $7.0 \pm 0.26)$ (Student's $t$-test, $t=13.94, p<0.05$ ). Meanwhile, neighboring local populations in Central Siberia could also substantially differ from each other by $\mathrm{mB}$ index. For instance, $A$. peninsulae populations from Krasnoyarsk region (localities 12-14, Figure 1) and the right bank of Yenisei River (locality 9) have relatively low $\mathrm{mB}$ index values $(7.7 \pm 0.5$ and $11.2 \pm 0.7$, respectively, Table 1), although they are surrounded by the local populations with very high $\mathrm{mB}$ index values (14.5-18.7). A similar situation is found in Khakassia, where the $\mathrm{mB}$ index reaches $23.0 \pm 4.6(n=3)$ in the north and $8.3 \pm 0.7$ in the south (Student's $t$-test, $t=5.5, p<0.05$ ).

The patterns of frequency distribution of $\mathrm{mB}$ index values (Figure 8 ) further reinforce the idea of adaptability of not just presence of $B$ chromosomes but the presence of their certain mass in A. peninsulae cells. Mice carrying both very low and very high $\mathrm{mB}$ index value were rarely met in examined populations. More than half of individuals have $\mathrm{mB}$ index between 4 and 11 .

In view of ecological prosperity of $A$. peninsulae, having wide species range and high adaptive potential, occupying various habitats, we assume that high Bs variety at least does not deteriorate the species adaptability. It is testified both by the fact that almost all karyotypes carry Bs and that Bs total 
masses within cells ( $\mathrm{mB}$ index) have mainly average values. Many issues are likely to be removed after discovering Bs active genes or ascertaining an interaction system between $\mathrm{A}$ and $\mathrm{B}$ chromosomes. For instance, ribosomal genes of $A$. peninsulae have been already found [23].

From the other point of view, high polymorphism of quantity and composition of B chromosomes does not support the idea of strong control by the selection. The high proportion of unique $B$ combinations evidently confirms it.

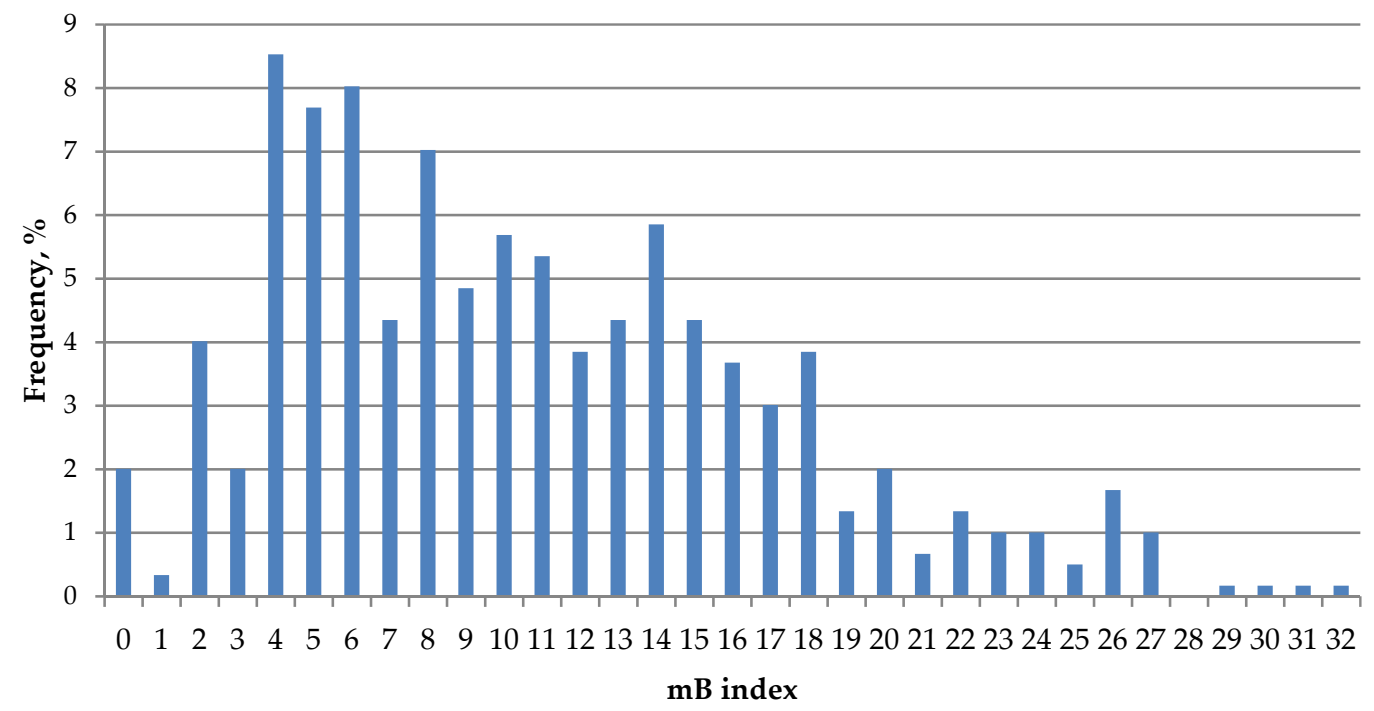

Figure 8. Frequency distribution of $\mathrm{mB}$ index values across studied A. peninsulae local populations.

Thus, the specific features and the structure of $\mathrm{B}$ chromosomes, found in our research, make $A$. peninsulae a promising model for studying mammalian Bs. Further investigation of B chromosome population variability and its relation to other phenomenon of chromosome instability of DNA sequences in A and B chromosomes would enable the clarification of microevolutional processes in mammals.

Author Contributions: Conceptualization, Y.M.B. and I.A.Z.; methodology, Y.M.B.; investigation, I.A.Z.; resources, Y.M.B.; writing-original draft preparation, I.A.Z and Y.M.B.; writing - review and editing, Y.M.B. and I.A.Z.; visualization, I.A.Z., data curation, I.A.Z.

Funding: This research received no external funding.

Conflicts of Interest: The authors declare no conflict of interest.

\section{References}

1. Wójcik, J.M.; Wójcik, A.M.; Macholan, M.; Pialek, J.; Zima, J. The mammalian model for population studies of B chromosomes: The wood mouse (Apodemus). Cytogenet. Genome Res. 2004, 106, 264-270. [CrossRef] [PubMed]

2. Bekasova, T.S.; Vorontsov, N.N.; Korobitsyna, K.V.; Korablev, V.P. B-chromosomes and comparative karyology of the mice of the genus Apodemus. Genetica 1980, 52, 33-43. [CrossRef]

3. Bekasova, T.S.; Vorontsov, N.N. Populational chromosome polymorphism in Asiatic Forest mice Apodemus peninsulae. Russ. J. Genet. 1975, 11, 89-94.

4. Bekasova, T.S. B-chromosomes of Asiatic wood mice Apodemus peninsulae (Rodentia, Muridae). Voprosy Izmenchivosti i Zoogeographii Mlekopitaushih 1984, 14-29.

5. Borbiev, T.E.; Kolomiets, O.L.; Borisov, Y.M.; Safronova, L.D.; Bogdanov, Y.F. Synaptonemal complexes of A and B-chromosomes in spermatocytes of the East Asiatic mouse Apodemus peninsulae. Tsitologiya 1990, 32, 193-196.

6. Borisov, Y.M.; Afanas'ev, A.G.; Lebedev, T.T.; Bochkarev, M.N. Multiplicity of B microchromosomes in a Siberian population of mice Apodemus peninsulae ( $2 \mathrm{n}=48+4-30$ B-chromosomes). Russ. J. Genet. 2010, 46, 705-711. [CrossRef] 
7. Borisov, Y.M.; Malygin, V.M. Cline variability of the B chromosome system in Apodemus peninsulae (Rodentia, Muridae) from the Buryatia and Mongolia. Tsitologiya 1991, 33, 106-111.

8. Borisov, Y.M. Instability of B-chromosomes in somatic and germline cells of Apodemus peninsulae. Russ. J. Genet. 2008, 44, 959-965. [CrossRef]

9. Borisov, Y.M.; Sheftel, B.I.; Safronova, L.D.; Aleksandrov, D.Y. Stability of the population variants of the B-chromosome system in the East-Asian Mouse Apodemus peninsulae from the Baikal region and Northern Mongolia. Russ. J. Genet. 2012, 48, 1020-1028. [CrossRef]

10. Kartavtseva, I.V.; Roslik, G.V. A complex B chromosome system in the Korean field mouse, Apodemus peninsulae. Cytogenet. Genome Res. 2004, 106, 271-278. [CrossRef] [PubMed]

11. Kral, B. Chromosome characteristics of certain murine rodents (Muridae) of the Asiatic part of the USSR. Zool. Listy 1971, 20, 331-347.

12. Radjabli, C.I.; Borisov, Y.M. Variants of the system of supernumerary chromosomes in continental forms of Apodemus peninsulae (Rodentia, Muridae). Dokl. Acad. Nauk SSSR 1979, 248, 979-981.

13. Roslik, G.V.; Kartavtseva, I.V. B chromosome morphotypes of Apodemus peninsulae (Rodentia) from the Russian Far East. Tsitologiia 2012, 54, 66-77. [PubMed]

14. Volobuev, V.T. Karyological analysis of three Siberian populations of Asiatic wood mouse, Apodemus peninsulae (Rodentia, Muridae). Dokl. AN SSSR 1979, 248, 1452-1454.

15. Vorontsov, N.N.; Bekasova, T.S.; Kral, B.; Korobitsyna, K.V.; Ivanitskaya, E.Y. On specific status of Asian wood mice of genus Apodemus (Rodentia, Muridae) from Siberia and Far East. Zool. Zhurnal 1977, 56, 437-450.

16. Wang, J.; Zhao, X.; Qi, H.; Koh, H.S.; Zhang, L.; Guan, Z.; Wang, C.H. Karyotypes and B chromosomes of Apodemus peninsulae (Rodentia, Mammalia). Acta Theriol. Sin. 2000, 20, 289-296.

17. Zima, J.; Macholan, M. B-chromosomes in the wood mice (genus Apodemus). Acta Theriol. 1995, 40, 75-86. [CrossRef]

18. Vujosevic, M.; Blagojevic, J. B chromosomes in populations of mammals. Cytogenet. Genome Res. 2004, 106, 247-256. [CrossRef] [PubMed]

19. Borisov, Y.M. Cytogenetic structure of Apodemus peninsulae (Rodentia, Muridae) population on the coast of Teletskoye Lake (Altai). Russ. J. Genet. 1990, 26, 1212-1220.

20. Hayata, J. Chromosomal polymorphism caused by supernumerary chromosomes in field mouse, Apodemus giliacus. Chromosoma 1973, 42, 403-414. [CrossRef] [PubMed]

21. Borisov, Y.M. System of B chromosomes in wood mouse as an integrating and differentiating characteristic of populations. Dokl. Akad. Nauk SSSR 1986, 288, 720-724.

22. Rubtsov, N.B.; Karamysheva, T.V.; Andreenkova, O.V.; Bochkarev, M.N.; Kartavtseva, I.V.; Roslik, G.V.; Borisov, Y.M. Micro B chromosomes of Korean field mouse Apodemus peninsulae (Rodentia, Murinae): Morphology, DNA contents, and evolution. Cytogenet. Genome Res. 2004, 106, 289-294. [CrossRef] [PubMed]

23. Rubtzov, N.B.; Borissov, Yu.M.; Karamysheva, T.V.; Bochkarev, M.N. The mechanisms of formation and evolution of B chromosomes in Korean field mice Apodemus peninsulae (Mammalia, Rodentia). Russ. J. Genet. 2009, 45, 389-396. [CrossRef]

24. Volobuev, V.T. B-chromosome system of the Asiatic wood mice Apodemus peninsulae (Rodentia, Muridae). I. Structure of karyotype, G- and C-bands, and the character of variation of B-chromosomes. Russ. J. Genet. 1980, 16, 1277-1284.

25. Volobuev, V.T. The B-chromosome system of mammals. Genetica 1980, 52, 333-337.

26. Volobuev, V.T. B-chromosome system of the mammals. Caryologia 1981, 34, 1-23. [CrossRef]

27. Ford, C.F.; Hamerton, J.L. A colchicine hypotonic citrate squash preparation for mammalian chromosomes. Stain Technol. 1956, 31, 247-251. [CrossRef] [PubMed]

28. StatSoft. Statistica Electronic Manual, version 8; Statsoft Inc.: Tulsa, OK, USA, 2008; Available online: http:/ / www.statsoft.com/Textbook (accessed on 30 August 2018).

(C) 2018 by the authors. Licensee MDPI, Basel, Switzerland. This article is an open access article distributed under the terms and conditions of the Creative Commons Attribution (CC BY) license (http:// creativecommons.org/licenses/by/4.0/). 